\title{
Strategi Pemasaran untuk Industri FMCG pada Era Covid-19
}

\author{
Grace Putlia $^{1}$, Cecilia Aurel Alphin ${ }^{2}$ \\ ${ }^{1,2}$ Universitas Bunda Mulia
}

Kampus Serpong: Jl. Jalur Sutera Barat kav 7-9, Alam Sutera, Tangerang, Banten 15143, Indonesia

e-mail: 1'gputlia@bundamulia.ac.id, ${ }^{2}$ ceciliaaure1227@gmail.com

\begin{abstract}
Informasi Artikel
Diterima: 19-12-2020

Direvisi: 18-01-2021

Disetujui: 20-01-2021

Abstrak

Dampak pandemi virus Covid-19 sangat terasa di dunia bisnis dan ekonomi. Dalam waktu yang cukup singkat, pola pemasaran pun berubah terlebih ketika diberlakukan social distancing dan Pembatasan Sosial Berskala Besar (PSBB). Menteri keuangan Sri Mulyani Indrawati menyebut sejumlah sektor industri berpotensi meraup keuntungan di tengah pandemi ini. Namun tampaknya fenomena menarik disini adalah terungkapnya fakta yang mengatakan sebaliknya. Ketua Umum Gabungan Makanan \& Minuman Seluruh Indonesia (GAPMMI) Adhi Lukman mengungkapkan, konsumsi rumah tangga turun 5,02\% ke 2,84\% selama Q1, dengan $44 \%$ berasal dari kontribusi makanan dan minuman. Berdasarkan fenomena yang ada, maka penelitian kualitatif dengan desain studi kasus ini mengulas lebih dalam melalui penelitian ini yang berjudul Strategi Pemasaran untuk Industri FMCG Pada Era Covid-19. Seluruh informan, secara dominan menyatakan hal sama bahwa dari 3 jenis kategori produk FMCG produk makanan dan minumanlah yang menduduki peringkat pertama untuk dilakukannya pembelian dalam setiap bulannya atau menjadi prioritas. Hasil akhir menunjukkan bahwa dari ke-27 informan secara dominan memiliki pernyataan yang sama perihal media yang digunakan dalam melakukan pembelian dari tiga kategori produk FMCG yang ada - penggunaan media yang menduduki peringkat pertama dilihat dari frekuensi beli yaitu marketplace sejumlah 16 orang informan, peringkat kedua yaitu social media sejumlah 5 orang informan, peringkat ketiga yaitu e-commerce sejumlah 3 orang informan, peringkat keempat yaitu reseller sejumlah 2 orang informan, peringkat kelima atau yang terakhir yaitu search engine sejumlah 1 orang informan.
\end{abstract}

Kata Kunci: covid-19; FMCG; strategi pemasaran

\begin{abstract}
The impact of the Covid-19 virus pandemic has been felt in the business and economic world. In a relatively short time, the marketing pattern also changed, especially when social distancing and large-scale social restrictions (PSBB) were implemented. Finance Minister Sri Mulyani Indrawati said a number of industrial sectors have the potential to reap profits amid this pandemic. However, it seems that an interesting phenomenon here is the unfolding of facts that say otherwise. Chairman of the Indonesian Food \& Beverage Association (GAPMMI) Adhi Lukman said household consumption fell 5.02\% to $2.84 \%$ during Q1, with $44 \%$ coming from the contribution of food and beverages. Based on existing phenomena, qualitative research with this case study design examines more deeply through this research entitled Marketing Strategy for the FMCG Industry in the Covid-19 Era. All informants, predominantly stated the same thing, that of the 3 types of FMCG product categories, food and beverage products were in the first rank for purchases every month or were a priority. The final result shows that of the 27 informants dominantly have the same statement regarding the media used in making purchases from the three existing FMCG product categories - media use is ranked first seen from the buying frequency, namely the marketplace with 16 informants, second place is 5 social media informants, the third rank is e-commerce with 3 informants, the fourth rank is resellers with 2 informants, the fifth rank or the last one is the search engine with 1 informant.
\end{abstract}

Keywords:covid-19; FMCG; marketing strategy

\section{Pendahuluan}

Pandemi Covid-19 masih menghantui khususnya Indonesia. Sejak kasus pertama diumumkan, lonjakan pasien positif terus terjadi dan kian meningkat (https://www.merdeka.com).
Presiden Joko Widodo mengumumkan secara resmi kasus pertama Covid-19 di Indonesia di Istana Negara tanggal 2 Maret 2020. Secara lebih rinci mengenai pergerakan kasus positif Covid-19 dapat dilihat pada Gambar 1.: 


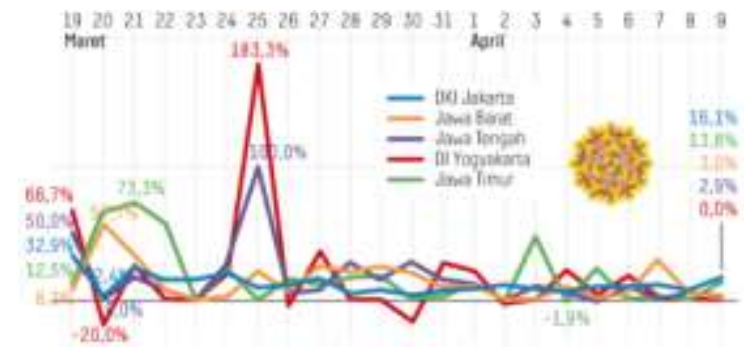

Sumber: https://corona.jakarta.go.id/id

Gambar 1. Pergerakan kasus positif covid-19

Dampak pandemi virus Covid-19 sangat terasa di dunia bisnis dan ekonomi begitu banyak berpengaruh dalam berbagai sektor. Salah satu sektor yang terdampak dan begitu terasa adalah sektor ekonomi (Sumarni, 2020). Lebih lanjut, penelitian McKibbin \& Fernando (2020), juga menyatakan bahwa pandemi Covid-19 dapat secara signifikan berdampak pada ekonomi global dalam jangka pendek.

Dalam waktu yang cukup singkat, pola pemasaran pun berubah terlebih ketika diberlakukan social distancing dan Pembatasan Sosial Berskala Besar (PSBB). Chairman TRAS N CO Indonesia, Tri Raharjo, menyebut bahwa dampak dari bencana virus Covid-19 memukul banyak sektor bisnis di Indonesia namun demikian ada pula beberapa sektor bisnis yang berpotensi stabil dan mengalami kenaikan seperti produk kesehatan yang dibutuhkan saaat pandemi, e-commerce, minimarket, toko sembako, apotek, toko jamu, provider internet, jasa penyedia video conference, aplikasi belajar dari rumah, dan lainnya (https://www.wartaekonomi. co.id).

Sejalan dengan hal tersebut, Menteri keuangan Sri Mulyani Indrawati menyebut sejumlah sektor industri berpotensi meraup keuntungan di tengah pandemi ini. "Memang Covid-19 menimbulkan dampak negatif cukup dalam bagi semua negara. Namun tidak semua sektor alami dampak negatif, ada sektor yang diperkirakan menjadi winner," ujar Sri Mulyani dalam rapat kerja bersama Komisi XI DPR secara virtual di Jakarta, Senin (6/4/2020) dilansir Kantor Berita Antara (https://www.antaranews.com). Menurut Sri Mulyani, setidaknya enam sektor berpotensi meraup untung di tengah pandemi ini. Sektor tersebut yaitu: tekstil dan produksi tekstil; kimia, farmasi, dan alat kesehatan; makanan dan minuman; elektronik; jasa telekomunikasi; dan jasa logistik.

Namun tampaknya fenomena menarik disini adalah terungkapnya fakta yang mengatakan sebaliknya. Kepala BPS Suhariyanto mengatakan tingkat konsumsi rumah tangga sepanjang 2019 sebesar 5,04 persen. Konsumsi rumah tangga meliputi barang konsumsi (consumers good), yaitu semua jenis barang tahan lama maupun tidak tahan lama yang digunakan untuk keperluan rumah tangga https://www.bps.go.id). Realisasi itu melambat dibandingkan dengan posisi 2018 lalu yang sebesar
$5,05 \%$. "Kami perlu mewaspadai (penurunan daya beli masyarakat). Pertumbuhannya tidak seperti sebelumnya," ucap Suhariyanto. Ia memaparkan beberapa pertumbuhan beberapa komponen memang melambat sepanjang 2019. Hal itu terlihat pada tingkat konsumsi industri makanan dan minuman (mamin) yang hanya tumbuh 5,16\% sepanjang 2019, sedangkan pada 2018 mencapai $5,22 \%$ (https://www.cnnindonesia.com).

Fast Moving Consumer Goods (FMCG) merupakan barang-barang "non-durable" yang diperlukan untuk penggunaan sehari-hari. Konsumen biasanya membeli produk kategori ini sekurangnya sekali dalam sebulan. Di semua negara, konsumen mengeluarkan anggaran paling besar pada sektor ini. Produk FMCG dapat dikelompokkan dalam tiga kategori produk, yaitu perawatan pribadi (personal care), perlengkapan rumah tangga (household care), serta makanan dan minuman (food \& beverages). Produk perawatan pribadi seperti pasta gigi, shampoo, kosmetik, parfum, dan lain-lain. Perlengkapan rumah tangga seperti sabun cuci, pembasmi serangga, dan lain-lain. Food \& beverages misalnya minuman ringan, teh, kopi, sayuran, dan sebagainya (https://supplychainindonesia.com/).

Ketua Umum Gabungan Makanan \& Minuman Seluruh Indonesia (GAPMMI) Adhi Lukman saat webinar Markplus, Selasa (19 Mei 2020) mengungkapkan, "Konsumsi rumah tangga turun $5,02 \%$ ke $2,84 \%$ selama Q1, dengan $44 \%$ berasal dari kontribusi makanan dan minuman. Padahal pengeluaran per kapita masyarakat kita $50 \%$ nya untuk pangan, dengan porsi pangan olahan mencapai 17\%." Maka tidak heran ada koreksi prediksi pertumbuhan industri makanan dan minuman di mana tahun lalu mencapai $7,97 \%$. Adhi memprediksi selama 2020 hanya akan tumbuh 4-5\% saja dari prediksi awal (https://www.medcom.id/ekonomi/bisnis).

"Melihat permasalahan tersebut, para pelaku brand harus menyikapinya dengan cepat dan tepat untuk mengubah strategi penjualannya. Diharapkan tidak terjadi drop penjualan yang signifikan saat diberlakukannya social distancing," kata Tri yang menjabat sebagai Chairman Komunitas Brand Network (IBN), Senin (13/4/2020). Untuk tetap dapat bertahan di tengah pandemi ini, lanjut Tri para pelaku brand harus bisa menyiasatinya. Mulai dari fokus ke pemasaran digital melalui website yang dijadikan e-commerce, social media, search engine, penjualan melalui marketplace, dan membentuk tim reseller untuk menjual produknya.

"Dalam masa pandemi Covid-19 ini, pemasar harus cepat beradaptasi seiring dengan diberlakukannya social distancing. Karena sudah pasti sangat memengaruhi perubahan besar dalam tren perilaku konsumen dalam berbelanja," papar Tri. Pemerintah sendiri telah menetapkan social 
distancing yang hingga per Agustus 2020 masih terus diperpanjang. Tentunya, para pemasar perlu menyikapinya dengan membuat strategi yang tepat, baik saat masa pandemi berlangsung maupun setelah pandemi berakhir (https://www.wartaekonomi. co.id/).

Selain penurunan konsumsi, terjadi juga pergeseran kebiasaan konsumen. Menurut Adhi Lukman, kini masyarakat lebih aware terhadap makanan organik. Channel penjualan juga mulai bergeser online. Plus karena kondisi darurat Covid19, masyarakat juga mulai aware menabung. Lalu terkait brand, di mana sekarang masyarakat tampak lebih peduli kepada fungsi dibanding nama produk (https://industri.kontan.co.id/).

Kebutuhan dan keinginan konsumen memang sangat bervariasi dan dapat berubah-ubah karena adanya faktor yang memengaruhi konsumen dalam melakukan pembelian, terlebih pada masa pandemi Covid-19. Oleh karena itu, seorang pemasar perlu untuk memahami perilaku konsumen supaya kegiatan pemasaran yang dilaksanakan dapat berjalan secara efektif dan efisien.

Beberapa pengertian perilaku konsumen yang dikemukakan oleh para ahli diantaranya adalah menurut Schiffman \& Kanuk (2010), mendefinisikan bahwa perilaku konsumen adalah perilaku yang diperlihatkan konsumen dalam mencari, membeli, menggunakan, mengevaluasi, dan menghabiskan produk dan jasa yang mereka harapkan akan memuaskan kebutuhan mereka. Menurut Fadila \& Ridho (2013), perilaku konsumen adalah tindakan yang langsung terlibat dalam memperoleh, pengkonsumsi dan penghabisan produk/jasa, termasuk proses yang mendahului dan menyusul tindakan ini.

Pemahaman terhadap perilaku konsumen bukanlah pekerjaan yang mudah tetapi cukup sulit dan kompleks. Hal ini disebabkan oleh banyaknya variabel-variabel yang memengaruhinya dan variabel-variabel tersebut cenderung saling berinteraksi. Namun demikian, apabila hal tersebut dapat dilakukan maka suatu perusahaan akan dapat meraih keuntungan yang jauh lebih besar daripada pesaingnya karena dengan memahami perilaku konsumen maka perusahaan tersebut dapat memberikan kepuasan secara lebih baik.

Beberapa media e-marketing yang dapat diusulkan adalah: e-commerce, social media, search engine, marketplace, dan reseller. E-commerce didefinisikan sebagai transaksi komersial yang melibatkan pertukaran nilai yang dilakukan melalui atau menggunakan teknologi digital antara individu (Laudon \& Traver, 2017). Ardianto (2011), dalam buku Komunikasi 2.0 mengungkapkan, bahwa media sosial online, disebut jejaring sosial online bukan media massa online karena media sosial memiliki kekuatan sosial yang sangat memengaruhi opini publik yang berkembang di masyarakat. Sedangkan Febrian (2007), menyatakan fungsi umum search engine adalah mempermudah manusia memperoleh informasi, bahkan untuk memenuhi beberapa kebutuhannya tanpa terbatas waktu dan tempat. Menurut Brunn, Jensen, \& Skovgaard (2002), e-marketplace adalah wadah komunitas bisnis interaktif secara elektronik yang menyediakan pasar dimana perusahaan dapat ambil andil dalam B2B e-commerce dan atau kegiatan $e$-business lain. Menurut Serfiyani, Hariyani, \& Purnomo (2013), mengatakan bahwa reseller yaitu penjualan kembali atau orang yang melakukan penjualan dari produk orang lain melalui website mereka dengan satu kesepakatan.

\section{Metode Penelitian}

Metode penelitian yang digunakan dalam penelitian ini adalah metode kualitatif (qualitative research). Menurut Lestari \& Sukmawan (2018), menjelaskan bahwa metode kualitatif merupakan sebuah prosedur penelitian yang menghasilkan data deskriptif berupa kata-kata tertulis atau lisan dari orang-orang dan perilaku yang dapat diamati. Menurut Nurgianti (2017), menyatakan bahwa metode penelitian kualitatif adalah metode penelitian yang berlandaskan pada filsafat postpositivisme, digunakan untuk meneliti pada kondisi objek yang alamiah, (sebagai lawannya adalah eksperimen) dimana peneliti adalah sebagai instrumen kunci.

Penelitian kualitatif tidak mengutamakan besarnya sampel. Jika data yang terkumpul sudah mendalam dan bisa menjelaskan fenomena yang diteliti, maka tidak perlu mencari informan lainnya. Menurut Kriyantono (2009), penelitian kualitatif lebih menekankan pada persoalan kedalaman (kualitas) data bukan banyaknya (kuantitas) data.

Pada penelitian kualitatif pengembangan instrumen mengandalkan triangulasi. Triangulasi sumber yaitu membandingkan dan mengecek balik derajat kepercayaan suatu informasi yang diperoleh melalui waktu dan alat yang berbeda dalam penelitian kualitatif. Hal ini dapat dicapai dengan jalan/cara salah satunya membandingkan hasil wawancara narasumber atau informan satu dengan narasumber/informan penelitian yang lain (Moleong, 2007).

Creswell (2014), menyatakan analisis data dalam penelitian kualitatif dilakukan pada saat pengumpulan data berlangsung dan setelah selesai pengumpulan data.

a) Pengumpulan Data

Pengumpulan data yang dilakukan peneliti melalui bentuk data berupa transkrip jawaban dari pedoman wawancara. Kemudian hasil bentuk data tersebut dikelompokkan.

b) Reduksi Data

Pada tahap ini kegiatan yang dilakukan adalah menyeleksi secara kasar dari catatan atau hasil jawaban pedoman wawancara.

- Mengelompokkan jawaban yang ada ke dalam bagian-bagian tertentu yang secara jelas berkaitan.

- Merumuskan aturan yang menetapkan 
inklusi setiap bagian kategori.

- Menjaga agar setiap kategori yang telah disusun satu dengan lainnya mengikuti prinsip.

c) Sintesisasi

- Mensintesiskan berarti mencari kaitan antara satu kategori dengan kategori lainnya.

- Kaitan satu kategori dengan kategori lainnya diberi nama/label lagi.

d) Penyajian Data

Pada tahapan ini kegiatan menarik data yang telah direduksi dan disintesiasi dengan tujuan menjawab pertanyaan penelitian sekaligus penarikan kesimpulan. Data penelitian dapat disajikan dalam bentuk uraian yang didukung dengan penelitian yang sebelumnya dengan teori-teori yang relevan terkait.

e) Penarikan Kesimpulan

Penarikan kesimpulan berdasarkan pengamatan yang menyeluruh dari hasil pedoman wawancara kepada informan.

\section{Hasil dan Pembahasan}

Berpedoman pada Kriyantono (2009), setelah data yang terkumpul sudah mendalam dan bisa menjelaskan fenomena yang diteliti, maka tidak perlu mencari informan lainnya. Berpedoman dengan hal tersebut, maka tercapailah data jenuh dengan terkumpul sejumlah 27 orang yang merupakan pengguna akhir (end user) dari berbagai latar belakang berbeda kisaran usia produktif kerja menurut Badan Pusat Statistik/BPS yaitu 15 - 64 tahun telah bersedia untuk menjadi informan berkenaan dengan masalah yang tengah diteliti.

Dari profil informan di atas, beberapa hal dapat disimpulkan. Dari 3 jenis kategori produk FMCG produk makanan dan minumanlah yang menduduki peringkat pertama untuk dilakukannya pembelian dalam setiap bulannya atau menjadi prioritas dari berbagai latar belakang yang ada yaitu sejumlah 14 informan disusul dengan produk perlengkapan rumah tangga yaitu sejumlah 8 informan dan terakhir adalah perawatan pribadi tangga yaitu sejumlah 5 informan. Setelah ditelusur lebih lanjut maka didapat data untuk setiap informan secara lebih terperinci, produk-produk yang menjadi prioritas adalah sebagai berikut: untuk produk makanan dan minuman yang jadi utama adalah beras, mi instan, air mineral, makanan kaleng, makanan beku, gula, teh, kopi; untuk perlengkapan rumah tangga yang jadi utama adalah handsanitizer, sabun cuci tangan, sabun cuci piring, sabun cuci baju, pakaian, bodycare; untuk produk perawatan pribadi yang jadi utama adalah vitamin \& suplemen, skin care (sabun muka, krim pelembab, scrub, serum).

Selesai dengan menganalisis profil informan, maka langkah selanjutnya olah data diawali coding data. Secara lebih rinci, coding data dapat dilihat seperti tampak di bawah ini pada Tabel 1:
Tabel 1. Coding Data

\begin{tabular}{cc}
\hline Variabel & Coding Data \\
\hline E-Commerce & EC (3) \\
Social Media & $\mathrm{SM} \mathrm{(5)}$ \\
Search Engine & $\mathrm{SE} \mathrm{(1)}$ \\
Marketplace & $\mathrm{MP}(16)$ \\
Reseller & $\mathrm{RS}(2)$ \\
\hline
\end{tabular}

Sumber: Peneliti, 2020

Selesai coding data, selanjutnya yang harus dilakukan yaitu olah data. Secara terperinci olah data dapat dilihat pada Tabel 2 dan Tabel 3:

Tabel 2. Pengklasteran Kategori berkenaan Persoalan Penelitian

\begin{tabular}{|c|c|c|c|c|}
\hline \multicolumn{5}{|c|}{$\begin{array}{l}\text { Apa Strategi Pemasaran untuk Industri FMCG pada } \\
\text { Era Covid-19? }\end{array}$} \\
\hline EC & SM & SE & MP & RS \\
\hline Cukup & Cukup & Kurang & Sangat & Kurang \\
\hline $\begin{array}{l}\text { Pengaruh } \\
\text { Sangat }\end{array}$ & $\begin{array}{c}\text { Pengaruh } \\
\text { Sangat }\end{array}$ & $\begin{array}{l}\text { Cukup } \\
\text { Pengaruh }\end{array}$ & $\begin{array}{l}\text { Pengaruh } \\
\text { Cukup }\end{array}$ & $\begin{array}{l}\text { Cukup } \\
\text { Pengaruh }\end{array}$ \\
\hline
\end{tabular}

Tabel 3. Klaster Kategori, Pola, dan Konsep

\begin{tabular}{ll}
\hline \multicolumn{2}{c}{ Apa Strategi Pemasaran untuk Industri FMCG pada } \\
Era Covid-19? \\
\hline $\begin{array}{c}\text { Klaster } \\
\text { Kategori }\end{array}$ & \multicolumn{1}{c}{ Pola dan Konsep } \\
\hline 1. Marketplace & Marketplace merupakan salah satu \\
2. Social Media & inovasi pembelanjaan saat ini dan \\
3. E-Commerce & dapat dilakukan setiap saat. Strategi \\
4. Reseller & ini menjadi yang paling difavoritkan \\
5. Search & masyarakat di masa pendemi. Sedikit \\
Engine & berbeda namun tetap berbasis internet \\
& adalah penggunaan social media yang \\
& sebenarnya fokus utama adalah untuk \\
& menjalin sosialisasi namun \\
& masyarakat mampu memanfaatkannya \\
& untuk melakukan transaksi sebab \\
dapat menjangkau masyarakat luas & dan sangat populer. Diikuti dengan $e$ - \\
& commerce, reseller, dan search \\
& engine. \\
\hline
\end{tabular}

Sumber: Peneliti, 2020

Olah data selesai dan hasil akhir menunjukkan bahwa dari ke-27 informan secara dominan memiliki pernyataan yang sama perihal media yang digunakan dalam melakukan pembelian dari tiga kategori produk FMCG yang ada - penggunaan media yang menduduki peringkat pertama dilihat dari frekuensi beli yaitu marketplace sejumlah 16 orang informan dimana dapat terlihat kandididat yang paling diminati sebagai berikut: Shopee, Tokopedia, dan Bukalapak; penggunaan media peringkat kedua dari frekuensi beli yaitu social media sejumlah 5 orang informan dimana terlihat kandidat yang paling diminati sebagai berikut: Instagram, YouTube, dan Facebook; penggunaan media peringkat ketiga dari frekuensi beli yaitu $e$ commerce sejumlah 3 orang informan dimana 
terlihat kandidat yang paling diminati sebagai berikut: Matahari Mall, Bhineka, Zalora; penggunaan media peringkat keempat dari frekuensi beli yaitu reseller sejumlah 2 orang informan dimana terlihat kandidat yang paling diminati sebagai berikut: reseller pakaian tidur (swap pajamas), reseller body care (Scarlett); penggunaan media peringkat kelima atau yang terakhir dari frekuensi beli yaitu search engine sejumlah 1 orang informan dimana terlihat kandidat yang paling diminati sebagai berikut: Google Chrome, FireFox, Bing. Hal tersebut dapat dilihat secara lebih rinci pada uraian di bawah ini.

Informan ke-4 merupakan informan dengan jumlah frekuensi beli produk paling sedikit dibandingkan para informan yang lainnya yaitu sebanyak $2 \times$ /bulan, yaitu berlatar belakang mahasiswa dengan pembelian prioritas produk perlengkapan Rumah Tangga (handsanitizer dan sabun cuci tangan) melalui social media. Uraian dari informan dapat dilihat seperti di bawah ini: Informan ke-4 menyatakan:

"Sebelum pandemi pun saya sudah terbiasa untuk membawa handsanitizer atau tissue basah dan kering tiap kali keluar rumah terutama sewaktu kuliah ya soalnya banyak kepake - misalnya sewaktu ke toilet, di kelas untuk lap meja, diskusi di tempat umum kayak taman atau perpustakaan, pas makan, dll. Kalau di rumah baru lebih sering pakai sabun cuci tangan. Untuk merek ganti-ganti tergantung mood atau ikut tren, saya suka eksplore segala sesuatu kan melalui social media khususnya Instagram makanya kalau ada produk baru saya selalu sering tertarik untuk mencobanya dan belinya juga sering lewat situ biasa dibawa nyambung ke WhatsApp atau e-mail. Saya lebih konsen beli barang-barang ini soalnya kalau kebutuhan pokok kayak makanan, minuman, dll itu mama yang urus lagipula uang saku kan terbatas",

Berbeda dengan informan ke-22 dengan jumlah frekuensi beli produk paling banyak dibandingkan para informan yang lainnya yaitu sebanyak $7 \times /$ bulan, yaitu berlatar belakang ibu RT dan karyawan dengan pembelian prioritas produk makanan dan minuman (beras, mi instan, air mineral) melalui marketplace. Uraian dari informan dapat dilihat seperti di bawah ini:

"Semenjak pandemi konsumsi saya dan keluarga semakin banyak apalagi semenjak belajar dan bekerja dari rumah ya. Jika dulu, rata-rata tiap bulan cukup belanja $4 \times /$ bulan saja, karena kan harus sesuaikan juga dengan jadwal ngantor. Tapi sekarang kalau belanjanya cuma $4 \times /$ bulan bahan makanan gak cukup bakal 1 bulan, udah keburu habis duluan. Jadi rata-rata sekarang 6-7×/bulan untungnya masih WFH sampai Desember makanya saya gak terlalu kerepotan. Yang menjadi pokok dan benar wajib beli adalah beras, mi instan banyakin yang cup dan air mineral galon. Amit-amit kalau ada apaapa makanan dan minuman di rumah bisa mencukupi untuk beberapa waktu soalnya kan dulu sempat dengar kalau bakal lockdown terus ngalamin tuh sulit cari beras dan gula dimana-mana jadi sejak itu sering paranoid. Makanya sekarang lebih baik nimbun deh terutama mi instan cup dan air mineral soalnya langsung bisa dikonsumsi. Saya selalu belanja lewat marketplace, soalnya selain praktis tidak perlu keluar rumah, pengirimannya pun cepat, dan harga juga lebih murah daripada toko atau supermarket."

Informan ke-15 dengan jumlah frekuensi beli produk sedang yaitu sebanyak $4 \times$ /bulan, berlatar belakang ibu RT dan karyawan dengan pembelian prioritas produk perawatan pribadi (vitamin \& suplemen, skincare) melalui $e$ commerce. Uraian dari informan dapat dilihat seperti di bawah ini:

"Dulu saya tidak terlalu peduli dengan kesehatan soalnya sebelum pandemi saya fit-fit saja dan jarang ada keluhan tentang sakit-penyakit namun beberapa kawan dan rekan ada yang terpapar jadi belakangan saya suka takut sendiri makanya mulai konsumsi vitamin \& suplemen lalu untuk skincare yang biasanya prioritas utama sekarang jadi nomor 2. Saya biasanya beli melalui Matahari Mall soalnya lebih terpercaya aja gitu kesannya ya. Vitamin \& suplemen saya yang bebas dijual ya kadang suka ganti-ganti sesuaikan kebutuhan saja seperti Enervon C, Ester C, ImBoost, Vitacimin, Natur-E. Kalau untuk skincare sekitaran Garnier, Ponds, Biore, Nivea, Cetaphil, BioDerma, Emina."

Informan ke-12 dengan jumlah frekuensi beli produk sedang yaitu sebanyak $4 \times$ /bulan, berlatar belakang karyawan dengan pembelian prioritas produk perlengkapan Rumah Tangga (pakaian tidur, bodycare) melalui reseller. Uraian dari informan dapat dilihat seperti di bawah ini:

"Kalau dulu pas jaman 'masih normal' saya sangat perhatikan masalah penampilan karena kan ngantor ketemu banyak orang ya, sekarang full WFH jadi pakaian kerja jarang kepake saya beralih beli pakaian rumah supaya suami gak bosen lihatnya itu-itu saja sekaligus meski di rumah aja tetep jaga tubuh dan kebersihan jadi saya konsen juga ke 
bodycare. Kalau pakaian tidur favorit saya dari Swap Pajamas tapi saya beli di reseller - teman saya. Ya itung-itung bagibagi rejekilah ya di jaman susah sekarang. Bahannya bagus, desainnya oke dan harga terjangkau. Kalau bodycare saya lagi suka produk Scarlet, wanginya enak-enak dan bisa mencerahkan, ini pun saya juga beli di reseller - teman saya lagi. Selain terpercaya karena teman sendiri, tidak perlu ongkos kirim kalau dari mereka tuh, langsung dianter sendiri dan gampang tinggal WA aja uangnya pas barang dianter jadi gak perlu transfer-transfer. Cuma memang sih, kalau resellernya gak kenal lebih enak online aja. Udah jarang ya jaman sekarang beli lewat reseller, dikatain kuno tapi menurut saya selama itu lebih mudah why not?"

Informan ke-6 dengan jumlah frekuensi beli produk sedang yaitu sebanyak $3 \times /$ bulan, berlatar belakang ibu Rumah Tangga dengan pembelian prioritas produk perawatan pribadi (vitamin \& suplemen) melalui search engine. Uraian dari informan dapat dilihat seperti di bawah ini:

"Jaman corona seperti sekarang saya lebih fokuskan untuk kesehatan jadi lebih prioritas untuk beli vitamin \& suplemen. Biasanya saya beli cari-cari atau lihat iklan di Google ya. Disana ka nada banyak tuh, barang serta keterangan barang juga harganya. Ya udah, saya cari-cari dulu terus ikutin aja petunjuknya. Beberapa kali kena tipu, barang gak dikirim-kirim sekarang sudah belajar dari pengalaman sudah tidak pernah seperti itu lagi."

Uraian di atas secara langsung menjawab persoalan penelitian mengenai strategi pemasaran apa yang cocok untuk industri FMCG pada era Covid-19, maka di dapat jawaban bahwa strategi pemasaran yang dirasa cocok bagi masyarakat adalah secara online. Namun, online atau berbasis internet dapat ditelusuri lebih lanjut dan terungkap beberapa strategi online yang dapat ditempuh yakni diperingkat pertama diduduki oleh marketplace, diperingkat kedua adalah social media, diperingkat ketiga e-commerce, diperingkat keempat reseller dan yang terakhir yaitu peringkat lima adalah search engine.

\section{Kesimpulan}

Informan secara total berjumlah 27 orang yaitu pengguna akhir (end user) dari berbagai latar belakang berbeda kisaran usia produktif kerja menurut Badan Pusat Statistik/BPS yaitu $15-64$ tahun; secara dominan menyatakan hal sama bahwa dari 3 jenis kategori produk FMCG produk makanan dan minumanlah yang menduduki peringkat pertama untuk dilakukannya pembelian dalam setiap bulannya atau menjadi prioritas yaitu sejumlah 14 informan disusul dengan produk perlengkapan rumah tangga yaitu sejumlah 8 informan dan terakhir adalah perawatan pribadi tangga yaitu sejumlah 5 informan.

Hasil akhir menunjukkan bahwa dari ke27 informan secara dominan memiliki pernyataan yang sama perihal media yang digunakan dalam melakukan pembelian dari tiga kategori produk FMCG yang ada - penggunaan media yang menduduki peringkat pertama dilihat dari frekuensi beli yaitu marketplace sejumlah 16 orang informan dimana dapat terlihat kandididat yang paling diminati sebagai berikut: Shopee, Tokopedia, dan Bukalapak; penggunaan media peringkat kedua dari frekuensi beli yaitu social media sejumlah 5 orang informan dimana terlihat kandidat yang paling diminati sebagai berikut: Instagram, YouTube, dan Facebook; penggunaan media peringkat ketiga dari frekuensi beli yaitu $e$ commerce sejumlah 3 orang informan dimana terlihat kandidat yang paling diminati sebagai berikut: Matahari Mall, Bhineka, Zalora; penggunaan media peringkat keempat dari frekuensi beli yaitu reseller sejumlah 2 orang informan dimana terlihat kandidat yang paling diminati sebagai berikut: reseller pakaian tidur (swap pajamas), reseller body care (Scarlett); penggunaan media peringkat kelima atau yang terakhir dari frekuensi beli yaitu search engine sejumlah 1 orang informan dimana terlihat kandidat yang paling diminati sebagai berikut: Google Chrome, FireFox, Bing.

Oleh karenanya, bidang tersebut dapat memanfaatkan marketplace sebagai strategi pemasaran tidak hanya untuk masa pandemi saja namun diramalkan dapat diterapkan juga untuk jangka waktu panjang sebab masyarakat merasakan banyak keuntungan melalui marketplace.

Rekomendasi untuk penelitian selanjutnya yang didasarkan pada keterbatasan penelitian agar dapat melakukan penelitian ulang secara kuantitatif atau menambahkan variabel penelitian agar strategi pemasaran yang dapat diimplementasikan dapat selalu mengikuti kondisi dan situasi terkini.

\section{Referensi}

Ardianto. (2011). Aspikom Komunikasi 2.0. Mata Padi Pressindo.

Brunn, P., Jensen, M., \& Skovgaard, J. (2002). eMarketplaces:: Crafting A Winning Strategy. European Management Journal, 20(3), 286298. https://doi.org/https://doi.org/10.1016/S0263- 
2373(02)00045-2

Creswell, J. W. (2014). Research Design: Qualitative, Quantitative, and Mix Methode Approach (Fourth ed). SAGE Publication. https://doi.org/10.2307/1523157

Fadila, D., \& Ridho, S. L. Z. (2013). Perilaku Konsumen. Citra Books Indonesia: Palembang.

Febrian, J. (2007). Kamus Komputer dan Teknologi Informasi. Penerbit Informatika: Bandung.

Kriyantono, R. (2009). Teknik Praktis Riset Komunikasi. Prenada Media Group: Jakarta.

Laudon, C. K., \& Traver, C. G. (2017). E-Commerce 2014 (10th ed.). Pearson Education: New York.

Lestari, Y. D., \& Sukmawan, S. (2018). Puitika Pentas Sabda Tama Catur Wedha Dalam Prosesi Malam Midodareni. Jurnal Ilmiah Edukasi \& Sosial, 9(1), 84-89.

McKibbin, W. J., \& Fernando, R. (2020). The Global Macroeconomic Impacts of COVID19: Seven Scenarios. CAMA - Centre for Applied Macroeconomic Analysis. https://doi.org/10.2139/ssrn.3547729

Moleong, L. J. (2007). Metodologi Penelitian Kualitatif. PT. Remaja Rosdakarya Offset: Bandung.
Nurgianti, A. (2017). Penerapan Model Discovery Learning Untuk Meningkatkan Percaya Diri Dan Hasil Belajar Siswa Pada Tema Indahnya Kebersamaan Subtema Kebersamaan Dalam Keberagaman (Penelitian Tindakan Kelas di Kelas IV SDN Neglasari 4 Kota Bandung). FKIP Unpas.

Schiffman, L. G., \& Kanuk, L. L. (2010). Consumer Behaviour (10th ed.). Prentice Hall: New Jersey.

Serfiyani, C. Y., Hariyani, I., \& Purnomo, S. D. (2013). Buku Pintar Bisnis Online dan Transaksi Elektronik. Gramedia Pustaka Utama: Jakarta.

Sumarni, Y. (2020). Pandemi Covid-19: Tantangan Ekonomi dan Bisnis. Jurnal Ekonomi Dan Perbankan Syariah, 6(2), 46-58.

Website:

https://www.merdeka.com

https://www.wartaekonomi.co.id

https://www.bps.go.id

https://www.cnnindonesia.com

https://supplychainindonesia.com/

https://www.medcom.id/ekonomi/bisnis

https://www.wartaekonomi.co.id/

https://industri.kontan.co.id/ 